\title{
事例紹介 NEDO「人間支援型ロボット実用化基盤技術開発」
}

\section{歩行補助ロボットの開発}

Development of Wearable Power Assist Locomotor

村 岡 慶 裕* 才藤 栄 一** * 藤田保健衙生大学 Yoshihiro Muraoka* and Eiichi Saitoh* *Fujita Health University

\section{1.はじめに}

ヒトが体を動かすとき，脳からの運動指令信号は，脊髄， 末梢神経, 筋肉へと伝わり, 筋収縮, すなわち運動が生じ る. 脊髄を損傷すると, 脳から筋肉への指令が遮断され, 運 動麻痺を呈する，損傷部位により，対麻痺（下肢麻痺）や 四肢麻痺（上下肢の麻痺）を発症する.

対麻痺者にとって, 車いすは, 利便性の高い唯一の実用 的移動手段である。しかし，低い目線での車いす生活は，対 麻痺者に大きな精神的負担を課し，さらには内臓疾患や関 節拘縮などの弊害をもたらしている，車いすの利便性を維 持し，適宜に立位および歩行を実現できる歩行補助装置の 開発が望まれる。

従来の歩行補助装具は, 股継手が両股関節の外側に位置 する「外側系」であり, 装着は床上で介助を要し, 起立動作 も容易ではなく，車いすとの併用が不可能であるため, 日 常生活ではほとんど使用されていない，一方，才藤らが本 邦に導入した股継手を大腿部の内側に配する「内側系」装 具 [1] [2] は，体幹部分の拘束感がなく，車いす上での装着， 取り外しが可能で, 日常生活での使用が可能である. しか し, 動力をもたない膝関節伸展位固定の下肢装具では, 歩 行器を用いた自力での起立動作は不可能であり, 歩行の際 にも身体への負担が過剩で, 約 5 分間の連続歩行が限界で あったため実用化には至らなかった。

本研究では, 対麻痺者が, 車いすを併用し, 歩行器を用い た自立的な起立と, より軽負担で平地歩行を実現する装着 型歩行補助ロボット「Wearable Power-Assist Locomotor: WPAL」の開発を目的とした。

\section{2. 開 発 体 制}

実用的な人間支援型ロボットを開発するためには，ユー ザから工学系開発者など多様な立場の者がお互いに意思疎 通をはかり，ユーザのニーズを把握して開発を行える体制

原稿受付 2008 年 8 月 5 日

キーワード: Paraplegia, Gait Analysis, Gait Assist Robot,

Primewalk, Orthosis

* $\overline{0}$ 470-1192 豊明市沓掛町田楽ヶ寉 1-98

* Toyoake-shi, Aichi

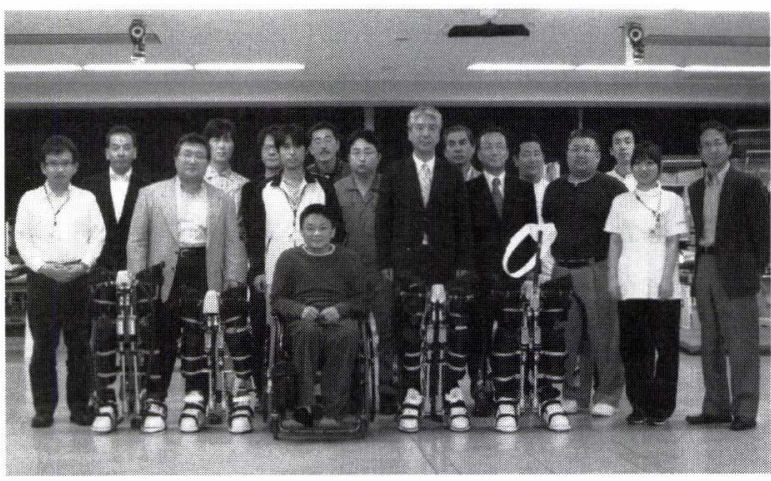

図 1 開発メンバー

づくりが必要不可欠である.

我々の研究開発メンバーは, 医師 4 名, 訓練を行う理学 療法士（以下 PT）兼工学博士 1 名, 工学博士 7 名, 義肢 装具士 1 名, PT3 名, エンジニア 4 名, デザイナー 2 名 と総勢 22 名の異種の専門家で構成され（図 1), 週に 2 日, 臨床を有する藤田保健衛生大学にて, 開発作業, 意見交換, 実証試験などを行った。ささらに，2名の医師は, 対麻疩者 でもあったので, 他の研究者は, ユーザのニーズを適切に 把握することが可能となった。

\section{WPAL の概要}

WPAL 本体は, 図 2 に示すように, 臨床用内側股継手付 長下肢装具に，その股・膝・足の各継手内側に計 6 個のモー 夕を付加した構成となっている. 制御器とバッテリは, 歩 行器に搭載した。ささらに、ロボット本体部分は, 図 3 に示 すように，車いす上も含め常時装着する装具部と，モジュ ラ構造のロボット部に分割可能となっており, 起立・歩行時 に，ロボット部を装具部に接合させる構造とした。この構 造により，ロボット部のモジュラ化による量産性と, 装具部 の可調整による個別性が確保される，特に，装具部は，感 覚の損なわれている対麻痺者の裖瘡を予防するために, 慎 重な個別対応が必要である。歩行器や足底には, 圧力セン サ, 電気角度計などを配置し, 歩幅, 歩行速度, 離地夕イ ミングの次歩行のパターンの推定を行った。本センサによ り，下肢運動の予測的制御 [3] と，離地モ二夕による安全性 


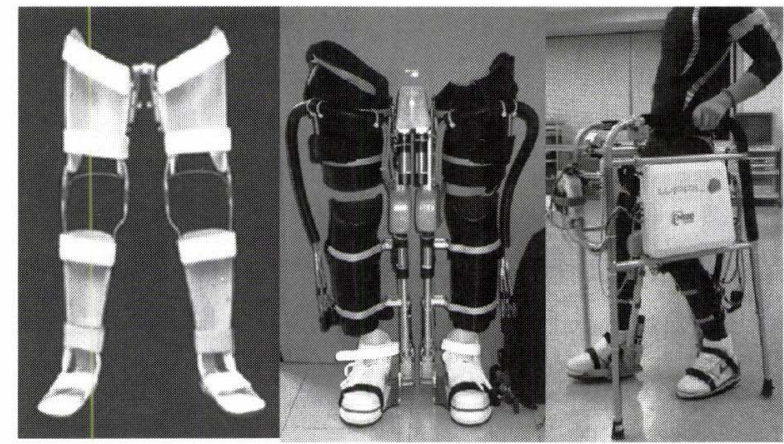

図 2 WPAL 構成 : 従来装具 (左) WPAL 本体 (中央) 歩行 器 (右)

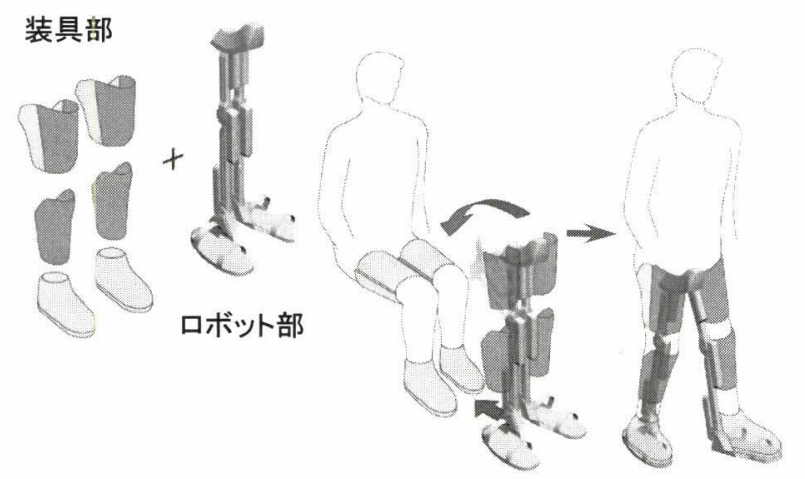

図 3 WPAL 本体構成（装具部とロボット部の分離可）と車い す上での装着手順

の向上を実現させた。

\section{WPAL 歩行訓練・評価システム}

乗り物であるWPAL は, 自動車と同様に転倒などの事 故が予想され，自動車教習に相当するWPAL 歩行訓練が, 実地使用時の安全対策上必要である. WPAL と自動車を比 較すると, 自動車教習所はリ八訓練室, 教習所教官は PT やリ八医，公安委員会はリ八医に相当する。

我々は, ユーザの操作能力の向上, そして, 実地前のユー ザおよび本体のリスク評価を，他患者への配慮を要し，時 間的・空間的制約のある臨床において実現するために，図 4 に示すトレッドミルと三次元動作解析装置を組み合わせ た省スペースの評価・訓練システム $[4] 〜[6]$ を構築した.さ らに，賏垂装置を設置したことで，安全を確保したうえで， 多数歩のデー夕の取得・訓練が可能となった.

\section{5. 実 証 試 験}

胸髄損傷 Th6-12の 5 名の被験者の参加により，従来の 装具（内側股継手付長下肢装具）に対する優位性を確認し た。まず，膝関節伸展位固定の従来の装具では実現不可能 であった歩行器使用による起立が，WPAL では全症例にお いて容易に実現された。平地歩行は，4名において歩行器 を用いた歩行, 1 名で医療スタッフ監視下での歩行器を用

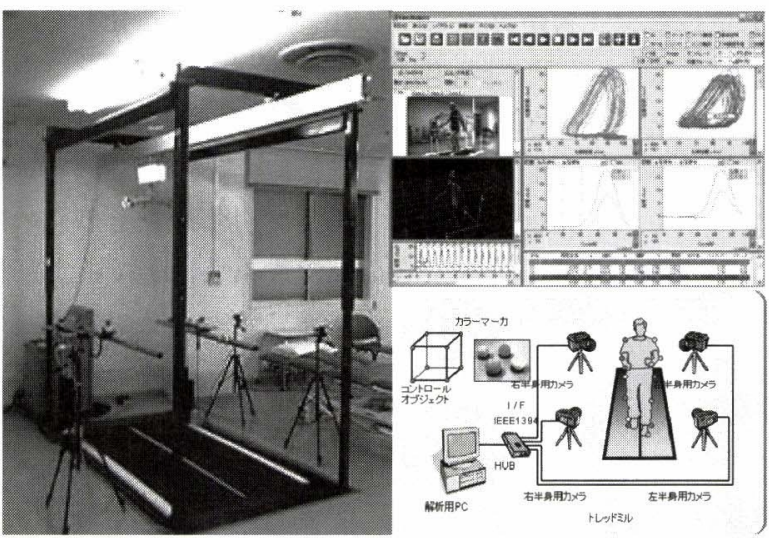

図 4 WPAL 歩行訓練システム: 外観 (左), 解析画面 (右上), 構成概念図（右下）

いた歩行が可能となった. WPALの一連操作をほぼ習得し た 1 名の被験者において, トレッドミル上での 7 分間の連 続歩行時の身体負担を計測し, 従来の装具と比較した. 歩 行時のエネルギー効率を示す指標である生理的コスト指数 $(\mathrm{PCI}($ 拍 $/ \mathrm{m})=[$ 歩行後心拍数 (拍/分) - 安静時心拍数 (拍/分) ] $\div$ 歩行速度 $(\mathrm{m} /$ 分 $))$, 心拍数, 自覚的運動強度 の指標である Borg 指数（運動負荷試験時に，本人に0を 安静，10 を非常にきつい，としたときの相当段階を申告さ せる), 上肢筋電図, いずれの指標においても，身体負担の 著明な軽減が確認された。これは, 特に遊脚期の膝関節が 屈曲可能になったことにより，トゥクリアランスを確保す るための左右への大きな重心移動の必要がなくなったこと が大きな要因と推察された。 また，同被験者による約 40 分 間（約 $580[\mathrm{~m}])$ の連続歩行が実現された.

\section{WPAL の発展}

将来的には，坂道および階段歩行も視野に入れている. さらに, WPAL 歩行訓練・評価システムによる WPAL 歩 行訓練は, 免荷式トレッドミル訓練において，これまで人 手で行っていたステッピング動作をロボットで実現した動 力機構付補装具であるロボット型歩行訓練機：Lokomat [7] と同等の機能も有しているので, 免荷式トレッドミル訓練 が目的としている中枢神経系の再構築を促進する歩行訓練 装置としての使用も可能と考えられる.しかも, 装着型口 ボットであるWPAL は, 日常生活のなかでの使用が，そ のまま訓練にもなっているという利点があり拡張性も高い. 脊髄再生医療が現実に医療現場に導入されたとき, WPAL は中枢神経再生後の中枢神経系再構築のための日常的歩行 訓練装置として, その威力を発揮するものと考えられる 8$]$.

\section{7. ま と}

WPAL は, ユーザの立場から生活のなかで必要とされる 機能を徹底追及し，開発されてきた，核となるロボット技 
術すなわちシーズが存在し，それを応用できる分野を探し て応用するといった従来の技術先行型の開発手順とは異な り，まず支援すべき明確な対象が存在し，それを原点とし て必要とされる機能を満たす技術を開発，あるいは適用す るというニーズ先行型の開発手順を採用した．そのために は, ニーズを的確に把握することが最重要課題であり, 開 発当初からユーザが開発者として参加することでこの課題 を克服した．実証試験においては, ユーザの参加が避けら れない. そのため, 参加者に対して, 安全面も含めた倫理 的配慮が必要であった。ささらには，ユーザの能力を最大限 に高める体制，すなわちロボットを使いこなすための訓練 体制も整備した．訓練を通して，ヒトとロボット双方がお 互いに融合し, 最終的に一つの系として, 歩行器による自 立的起立と平地歩行を達成した。この開発体制, 開発手順 こそが，人間支援型ロボット開発における実用化技術とい え, 個々のロボット技術にも増し, 大きな研究成果であっ たといえるであろう。

具体的成果としては, 対麻痺者が WPAL を装着し, これ まで不可能とされていた歩行器による車いすからの自力で の立ち上がりと，限界とされてきた 5 分間の連続歩行を大 きく上回る約 40 分間の連続歩行を世界で初めて実現した.

従来装具の二つの大きな課題を克服できたことから, 対 麻痺者の日常生活に扔ける歩行再建は, 実現にむけて大き く前進した。

謝辞本稿で取り上げた WPAL 開発研究は, 新エネ ルギー・産業技術総合開発機構 (NEDO) からの委託研究 による、また, 本研究成果は, アスカ株式会社 武満知彦 氏, 中村清和氏, 樋口励氏, 藤田保健衛生大学 鈴木亨教授,
藤野宏紀先生, 清水康裕先生, 田辺茂雄講師, 伊藤実和先 生, 土本有香先生, 窪田慎治先生, 東名ブレース 宇野秋 人氏, ティムス株式会社 林正康氏, 理化学研究所 向井 利春先生, 加藤陽先生, 高嶋一登先生, 愛知県立芸術大学 中島聡准教授, 本田敬先生, 名古屋大学 宇野洋二教授, 香 川高広助教, 豊橋技術科学大学 福村直博准教授 他との共 同研究による．稿を終えるにあたり諸先生に感謝致します。

\section{参 考 文 献}

[1] E. Saitoh, T. Suzuki, S. Sonoda, J. Fujitani, Y. Tomita and N. Chino: "Clinical experience with a new hip-knee-anklefoot orthotic system using a medial single hip joint for paraplegic standing and walking," Am. J. Phys Med Rehabil, vol.75, pp.198-203, 1996.

[2] 園田, 才藤, 富田, 田中, 山口, 村岡, 鈴木, 鈴木, 藤谷, 千野: “Walkabout と機能的電気刺激を用いた対麻盘歩行パターンの分析”, 臨床 リハビリテーション, vol.6, pp.508-512, 1997.

[3] 香川, 宇野, 村岡, 才藤： “加速度センサーを用いた滑らかさの規範 に基づく手先移動距離の推定”, 日本神経回路学会第 16 回全国大会講 演論文集, vol.16, pp.70-72, 2006.

[4] 大塚, 才藤, 寺西, 金田: “【リハビリテーション医学の進歩と展開】卜 レッドミル歩行分析と歩行訓練”，現代医療，vol.32，pp.1439-1444, 2000.

[5] 藤野, 米田, 松永, 才藤, 加藤, 大塚：“不全四肢麻瘏者のトレッドミ ル歩行訓練”, 日本脊髄障害医学会雑誌, vol.18, pp.186-187, 2005

[6] 大塚, 才藤, 村岡, 山村, 沢田: “トレッドミル歩行分析—リサージュ図形 を用いた新しい三次元動作解析法—”, 臨床脳波, vol.48, pp.541-546, 2006.

[7] G. Colombo, M. Joerg, R. Schreier and V. Dietz: "Treadmill training of paraplegic patients using a robotic orthosis," J. Rehabil. Res. Dev., vol.37, pp.693-700, 2000.

[8] 村岡, 田辺, 才藤, 香川, 宇野: “リハビリテーション工学の進歩と 応用歩行補助ロボットの開発と臨床”, The Japanese Journal of Rehabilitation Medicine, vol.44, no.1, pp.29-35, 2007.

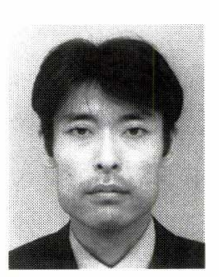

村岡慶裕（Yoshihiro Muraoka）

工学博士, 国立病院機構村山医療センター生 体機能制御解析室室長, 慶應義塾大学医学部訪 問准教授. 1995 年慶應義塾大学理工学部計測 工学科卒業. 慶應義塾大学理工学部助手, 藤田 保健衛生大学医療科学部准教授を経て, 2008 年 8 月より現職. 生体計測, 電気生理学等の 研究に従事.ロボットビジネス推進協議会, 宇宙軌道上の運動 検討委員会等に所属.

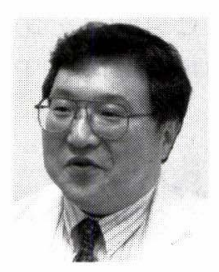

才藤栄—（Eiichi Saitoh）

医学博士, 日本リハビリテーション医学会専 門医. 1980 年慶應義塾大学医学部卒業. 現在 藤田保健衛生大学医学部リハビリテーション 医学講座教授。専門領域はリハビリテーショ ン医学, 摂食・曣下障害, 歩行再建, リハビ リテーション心理学など. 著書に『摂食・䤑下 リハビリテーション第 2 版』医歯薬出版 (2007), 『FIT プログ ラム』医学書院 (2003), 『リハビリテーション医療心理学キー ワード』文光堂 (1995) など. 社会活動として日本摂食・曣下 リハビリテーション学会理事長, 日本リハビリテーション医学 会理事, 日本義肢装具学会理事, Johns Hopkins 大学客員教授, Dysphagia Research Society 理事 (米国), Dysphagia 編集委 員など. 